\title{
Penghambatan Pertumbuhan Gulma Commelina diffusa oleh Pemberian Ekstrak Segar Daun Mikania micrantha
}

\section{Growth Supression on Commelina diffusa Weed by Application of Mikania micrantha Leaves Extract}

\author{
Natalia Puteri Widiastuti ${ }^{1}$, Sofyan Zaman ${ }^{2}$, dan Sudradjat ${ }^{2 *}$ \\ 'Program Studi Agronomi dan Hortikultura, Departemen Agronomi dan Hortikultura, Institut Pertanian Bogor \\ ${ }^{2}$ Departemen Agronomi dan Hortikultura, Fakultas Pertanian, Institut Pertanian Bogor \\ (Bogor Agricultural University), Jl. Meranti, Kampus IPB Darmaga, Bogor 16680, Indonesia
}

Diterima 13 Februari 2020/Disetujui 1 April 2020

\begin{abstract}
Commelina diffusa Burm. F. is known to have been resistant to several types of herbicides, so it needs an alternative way to control its growth. Mikania micrantha contains allelopathic compounds that can suppress the growth of plants nearby so that it can potentially be used as a bioherbicide. This research aimed to study the potentiality of $\underline{M}$. micrantha leaf extract to inhibit the growth of $\underline{\underline{C}}$. diffusa. This research was conducted at Cikabayan Experimental Station and Postharvest Laboratory, IPB University, from April to June 2019. A randomized complete block design was used in this research with extract concentration at $0.00,0.33,0.67,1.00,1.33,1.67$, and $2.00 \mathrm{~g}$ fresh weight $\mathrm{mL}^{-1}$ as treatments with four replications. Application of $\underline{M}$. micrantha leaf extract decreased the leaf number, increased toxicity rate, and death percentage of $\underline{C}$. diffusa. The experiment showed $\underline{M}$. micrantha leaf extract was able to suppress $\underline{C}$. diffusa leaf number up to 2 weeks after application (WAP). M. micrantha $1.15 \mathrm{~g} \mathrm{~mL}-1$ leaf extract caused toxicity on $\underline{C}$. diffusa growth at 1 WAP and caused the death

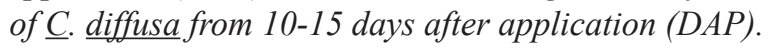

Keywords: bioherbicide, weeds, extract concentration, resistant, allelopathic compounds

\section{ABSTRAK}

Commelina diffusa Burm. F. diketahui telah resisten terhadap beberapa jenis herbisida sehingga alternatifpengendalian gulma tersebut perlu diketahui. Mikania micrantha merupakan salah satu jenis gulma yang mengandung senyawa alelopati yang dapat menekan pertumbuhan tanaman di sekitarnya sehingga berpotensi digunakan sebagai bioherbisida. Penelitian ini bertujuan mengetahui potensi ekstrak daun $\underline{M}$. micrantha sebagai bioherbisida untuk menghambat pertumbuhan gulma C. diffusa. Penelitian dilaksanakan di Kebun Percobaan Cikabayan dan Laboratorium Pascapanen, Institut Pertanian Bogor pada bulan April-Juni 2019. Rancangan percobaan yang digunakan adalah rancangan kelompok lengkap teracak (RKLT) faktor tunggal yaitu konsentrasi ekstrak daun $\underline{\text { M. }}$. micrantha sebesar 0.00, 0.33, 0.67, 1.00, 1.33, 1.67, dan $2.00 \mathrm{~g}$ bobot basah $m L^{-1}$, dengan 4 ulangan. Aplikasi ekstrak daun $\underline{M}$. micrantha mengurangi jumlah daun, meningkatkan skor toksisitas, dan meningkatkan persentase kematian gulma $\underline{C}$. diffusa. Hasil penelitian menunjukkan bahwa aplikasi ekstrak daun $\underline{M}$.

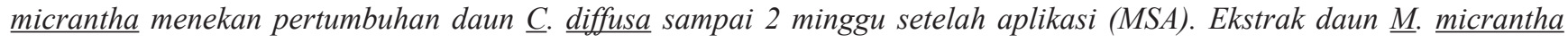
bersifat toksik bagi pertumbuhan $\underline{\underline{C}}$. diffusa pada 1 MSA dan menyebabkan kematian $\underline{C}$. diffusa mulai 10-15 hari setelah

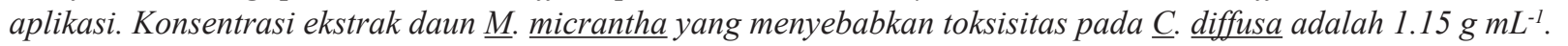

Kata kunci: bioherbisida, gulma, konsentrasi ekstrak, resisten, senyawa alelopati

\section{PENDAHULUAN}

Gulma perlu dikendalikan agar tidak menyebar ke area yang lebih luas karena gulma memiliki mekanisme

\footnotetext{
* Penulis untuk korespondensi. e-mail: sudradjat2011@gmail. com
}

penyebaran yang unik (Choudhury et al., 2016). Pengendalian gulma konvensional menggunakan herbisida sintetik dipandang mahal, dapat membahayakan kesehatan manusia, dan mencemari lingkungan (Shen et al., 2018). Selain itu, penggunaan herbisida yang sama dapat menyebabkan adanya gulma yang resisten (Dilipkumar et al., 2017). Oleh karena itu, salah satu upaya mengatasi 
dampak negatif herbisida sintetik adalah menggunakan bioherbisida karena peluang pencemaran lingkungan kecil (Riskitavani dan Purwani, 2013) dan potensial mengatasi masalah resistensi terhadap herbisida sintetis (Boyette et al., 2015)..

Mikania micrantha Kunth. merupakan gulma bagi tanaman budidaya yang mudah menyebar, mampu tumbuh pada berbagai kondisi agroekologi serta bersaing kuat dalam mengambil unsur hara (Adriadi et al., 2012). Bahkan, M. micrantha dapat menekan pertumbuhan gulma lain, seperti Cleome rutidosperma D.C dan Paspalum notatum Flugge (Pebriani et al., 2013), Cyperus iria dan Ageratum conyzoides (Sahid dan Yusoff, 2014), Melastoma affine D.Don (Hamidah et al., 2015) serta Mimosa pudica L (Adin et al., 2017). Ekstrak daun M. micrantha diketahui dapat menghambat perkecambahan tanaman hanjeli (Coix lacryma-jobi) (Li dan Jin, 2010) dan Arabidobsis thaliana (Xu et al., 2013).

Di sisi lain, gulma Commelina diffusa Burm. F. relatif sulit dikendalikan karena memiliki cara reproduksi menggunakan buku-buku yang terpotong (Isaac et al., 2013). C. diffusa diketahui resisten pada beberapa jenis herbisida, seperti 2.4-dichlorophenoxy-acetic acid (Isaac et al., 2007) dan dicamba (Mortensen et al., 2012).

Gulma M. micrantha potensial sebagai bioherbisida karena mengandung alelopati, diantaranya sesquiterpenoids (Nicollier dan Thompson, 1981) dan senyawa fenol (Dong et al., 2017). Senyawa fenol dapat menghambat pertumbuhan gulma berdaun lebar (Kusuma et al., 2017). Daun M. micrantha memiliki 25 senyawa terpenoid yang telah teridentifikasi (Bravo-Monzon et al., 2018). Komponen minyak atsiri utama dari biji dan bunga $M$. micrantha adalah linalool dan $\alpha$-pinene (Perez-Amador et al., 2010). Penelitian bertujuan mengetahui potensi ekstrak daun $M$. micrantha sebagai bioherbisida untuk menghambat pertumbuhan C. diffusa.

\section{BAHAN DAN METODE}

Penelitian dilakukan di rumah kaca Kebun Percobaan Cikabayan dan Laboratorium Pascapanen, Institut Pertanian Bogor pada bulan April-Juni 2019. Bahan yang digunakan dalam penelitian ini berupa daun $M$. micrantha dan stolon C. diffusa yang diperoleh dari Kebun Percobaan Sawah Baru IPB.

Penelitian dilakukan dengan menggunakan Rancangan Kelompok Lengkap Teracak (RKLT) dengan faktor tunggal dan 4 ulangan. Perlakuan yang digunakan adalah konsentrasi bioherbisida terdiri atas tujuh konsentrasi yaitu: 0.00 (kontrol), $0.33,0.67,1.00,1.33,1.67$, dan $2.00 \mathrm{~g}$ bobot basah $\mathrm{mL}^{-1}$. Sebagai pelarut digunakaan aquades.

Kegiatan penelitian diawali dengan menyiapkan ekstrak daun $M$. micrantha sebelum perlakuan dan disimpan di suhu ruang. Metode pembuatan ekstrak daun $M$. micrantha mengacu pada Puspita (2007). Daun M. micrantha yang bersih, segar, dan tidak rusak ditimbang sesuai dengan perlakuan, kemudian dihancurkan dengan pelarut aquades dengan menggunakan blender. Ekstrak yang diperoleh selanjutnya disaring dengan kasa.

Media tanam yang digunakan adalah tanah yang telah digemburkan, dibersihkan dari kotoran, dan telah disterilisasi. Persiapan bahan tanam C. diffusa dilakukan dengan memotong stolon dengan ukuran $\pm 10 \mathrm{~cm}$. Stolon gulma $C$. diffusa ditanam dalam polibag berisi media tanam sebanyak $\pm 250 \mathrm{~g}$. Jumlah polibag untuk setiap satuan percobaan yaitu 25 polibag. Aplikasi larutan ekstrak sesuai dengan perlakuan diberikan pada 5 minggu setelah tanam (MST) karena pada umur tersebut pertumbuhan gulma cenderung seragam. Volume semprot aplikasi ekstrak daun $M$. micrantha yaitu $500 \mathrm{~L} \mathrm{ha}^{-1}$. Aplikasi dilakukan menggunakan hand sprayer.

Peubah yang diamati terdiri atas pertumbuhan, skor toksisitas gulma, dan persentase kematian gulma $C$. diffusa. Pengamatan meliputi panjang gulma yang diukur dari permukaan tanah sampai ujung gulma, jumlah daun yang telah membuka sempurna, dan jumlah cabang yang terbentuk pada 1, 2, dan 3 minggu setelah aplikasi (MSA). Bobot kering gulma diperoleh pada 10, 20, dan 30 hari setelah aplikasi (HSA) dengan cara memotong gulma setinggi tanah, lalu dioven pada $80{ }^{\circ} \mathrm{C}$ selama 3 x 24 jam dan ditimbang. Skoring toksisitas dilakukan pada 1, 2, dan 3 MSA secara visual sesuai dengan metode Fuadi dan Wicaksono (2018). Penentuan skor yaitu sebagai berikut: 0 $=$ tidak terjadi keracunan (tingkat keracunan 0-5\%, bentuk dan warna daun normal), $1=$ keracunan ringan (tingkat keracunan 5-25\%, bentuk dan warna daun tidak normal), $2=$ keracunan sedang (tingkat keracunan 25-50\%, bentuk dan warna daun tidak normal), $3=$ keracunan berat (tingkat keracunan $50-75 \%$, bentuk dan warna daun tidak normal), dan $4=$ keracunan sangat berat (tingkat keracunan $>75 \%$, bentuk dan warna daun tidak normal).

Pengamatan persentase kematian gulma dilakukan pada 5, 10, 15, dan 20 HSA. Nilai persentase kematian gulma dihitung dengan rumus sebagai berikut:

Kematian gulma $=\frac{\sum \text { gulma yang mati }}{\sum \text { gulma yang ditanam }} \times 100 \%$

Analisis data dilakukan dengan menggunakan aplikasi SAS dan Microsoft excel. Data dianalisis dengan uji F pada taraf 5\%, apabila menunjukkan pengaruh nyata dilanjutkan dengan duncan multi range test (DMRT). Uji polinomial dilakukan untuk menentukan konsentrasi optimal ekstrak daun M. micrantha.

\section{HASIL DAN PEMBAHASAN}

\section{Kondisi Umum}

Gulma lain yang tumbuh pada polibag diantaranya Cyperus kyllingia, Euphorbia hirta, Mollugo pentaphylla, Oxalis corniculata, Phylantus niruri, dan Pilea microphylla (Gambar 1). Gulma lain tersebut disiangi setelah diamati. 


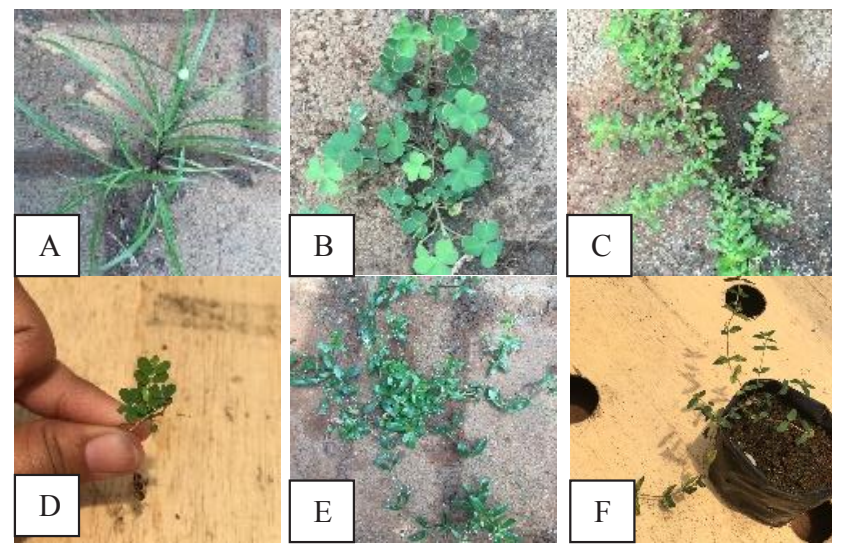

Gambar 1 Gulma yang tumbuh pada polibag: (A) Cyperus kyllingia, (B) Oxalis corniculata, (C) Pilea microphylla, (D) Phylantus niruri, (E) Mollugo pentaphylla, dan (F) Euphorbia hirta

Gulma C. diffusa yang mengalami keracunan menunjukkan gejala berupa perubahan warna daun menjadi kuning hingga kecoklatan (Gambar 2). Setelah itu, batang gulma $C$. diffusa juga menjadi layu dan kering. Tingkat keracunan yang tinggi dapat menyebabkan kematian pada C. diffusa.

\section{Pertumbuhan C. diffusa}

Ekstrak gulma $M$. micrantha mempengaruhi beberapa peubah pengamatan hingga 2 MSA (Tabel 1). Hal ini diduga karena gulma $C$. diffusa memiliki kemampuan yang baik dalam melakukan pertumbuhan kembali (regrowth).

Aplikasi ekstrak daun $M$. micrantha tidak mempengaruhi panjang gulma secara nyata (Tabel 2). Gulma C. diffusa yang diberi ekstrak daun M. micrantha dengan konsentrasi $0.33 \mathrm{~g} \mathrm{~mL}^{-1}$ memiliki rata-rata panjang gulma yang $15 \%$ lebih pendek dibandingkan dengan kontrol, sedangkan rata-rata panjang gulma yang diberi perlakuan konsentrasi $2 \mathrm{~g} \mathrm{~mL}^{-1}$ yaitu $13 \%$ lebih panjang dibandingkan dengan kontrol pada 1 MSA. Menurut Pebriani et al. (2013), ekstrak daun M. micrantha mengandung senyawa alelokimia yang dapat mengganggu aktivitas hormon

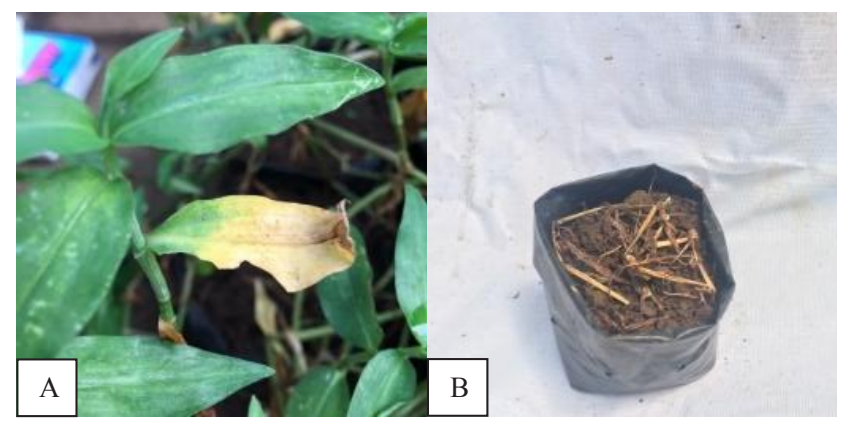

Gambar 2. Gejala keracunan pada gulma C. diffusa: (A) daun berwarna kuning, (B) batang berwarna kecoklatan dan kering sitokinin sehingga pembelahan dan pemanjangan sel terhambat dan pada gilirannya menghambat pertumbuhan panjang. Fariba et al. (2007) menyatakan bahwa senyawa alelopati dapat merangsang atau menghambat pertumbuhan tanaman tergantung dengan konsentrasi yang diberikan.

Aplikasi ekstrak daun M. micrantha memengaruhi jumlah daun gulma $C$. diffusa pada 1-2 MSA, tetapi tidak mempengaruhi pada 3 MSA (Tabel 3). Hal ini menunjukkan bahwa ekstrak daun $M$. micrantha efektif untuk mengendalikan gulma $C$. diffusa hingga 2 MSA. Aplikasi ekstrak daun $M$. micrantha dengan konsentrasi terendah yaitu $0.33 \mathrm{~g} \mathrm{~mL}^{-1}$ telah mampu menekan jumlah daun $C$. diffusa sebesar $48 \%$ pada 1 MSA.

Jumlah cabang gulma $C$. diffusa tidak dipengaruhi oleh pemberian ekstrak daun $M$. micrantha (Tabel 4). Namun, aplikasi ekstrak daun $M$. micrantha konsentrasi $0.33 \mathrm{~g} \mathrm{~mL}^{-1}$ menghasilkan jumlah cabang yang terendah pada $1 \mathrm{MSA}$ yaitu $37.27 \%$ lebih rendah dibandingkan kontrol.

Aplikasi ekstrak daun $M$. micrantha menyebabkan keracunan pada gulma $C$. diffusa pada 1 MSA (Tabel 5). Perbedaan konsentrasi ekstrak daun $M$. micrantha tidak

Tabel 1. Rekapitulasi sidik ragam

\begin{tabular}{|c|c|c|c|}
\hline Parameter & Umur & Uji F & KK \\
\hline \multirow[t]{3}{*}{ Panjang gulma } & $1 \mathrm{MSA}$ & tn & 21.57 \\
\hline & $2 \mathrm{MSA}$ & tn & 20.27 \\
\hline & $3 \mathrm{MSA}$ & tn & 16.99 \\
\hline \multirow[t]{3}{*}{ Jumlah daun } & $1 \mathrm{MSA}$ & $*$ & 22.81 \\
\hline & $2 \mathrm{MSA}$ & $* *$ & 18.82 \\
\hline & $3 \mathrm{MSA}$ & tn & 26.69 \\
\hline \multirow[t]{3}{*}{ Jumlah cabang } & $1 \mathrm{MSA}$ & tn & 28.20 \\
\hline & $2 \mathrm{MSA}$ & tn & 25.31 \\
\hline & $3 \mathrm{MSA}$ & tn & 21.77 \\
\hline \multirow[t]{3}{*}{ Skor toksisitas a } & $1 \mathrm{MSA}$ & $* *$ & 15.22 \\
\hline & $2 \mathrm{MSA}$ & tn & 19.46 \\
\hline & $3 \mathrm{MSA}$ & tn & 13.37 \\
\hline \multirow[t]{6}{*}{ Persentase kematian ${ }^{\text {a }}$} & $5 \mathrm{HSA}$ & tn & 54.48 \\
\hline & 10 HSA & * & 53.00 \\
\hline & 15 HSA & $* *$ & 51.53 \\
\hline & 20 HSA & tn & 60.60 \\
\hline & $25 \mathrm{HSA}$ & tn & 54.89 \\
\hline & 30 HSA & tn & 54.89 \\
\hline \multirow[t]{3}{*}{ Bobot kering a } & 10 HSA & tn & 12.26 \\
\hline & 20 HSA & tn & 16.30 \\
\hline & 30 HSA & tn & 16.00 \\
\hline
\end{tabular}

Keterangan: $* *$ ) berpengaruh sangat nyata pada taraf $1 \%$, *) berpengaruh nyata pada taraf $5 \%$, tn) tidak berpengaruh nyata, a data ditransformasi $\mathrm{ke} \sqrt{ }(\mathrm{x}+0.5)$, MSA $=$ minggu setelah aplikasi, HSA $=$ hari setelah aplikasi 
Widiastuti et al. / J. Agron. Indonesia 48(1):104-110

Tabel 2. Pengaruh ekstrak daun M. micrantha terhadap panjang C. diffusa

\begin{tabular}{lccc}
\hline \multirow{2}{*}{ Konsentrasi ekstrak } & \multicolumn{3}{c}{ Panjang gulma $(\mathrm{cm})$} \\
\cline { 2 - 4 } & $1 \mathrm{MSA}$ & $2 \mathrm{MSA}$ & $3 \mathrm{MSA}$ \\
\hline $0.00 \mathrm{~g} \mathrm{~mL}^{-1}$ (kontrol) & 51.95 & 70.68 & 70.10 \\
$0.33 \mathrm{~g} \mathrm{~mL}^{-1}$ & 44.04 & 54.24 & 59.17 \\
$0.67 \mathrm{~g} \mathrm{~mL}^{-1}$ & 48.07 & 64.96 & 69.65 \\
$1.00 \mathrm{~g} \mathrm{~mL}^{-1}$ & 50.79 & 59.02 & 68.65 \\
$1.33 \mathrm{~g} \mathrm{~mL}^{-1}$ & 42.57 & 47.44 & 55.33 \\
$1.67 \mathrm{~g} \mathrm{~mL}^{-1}$ & 44.44 & 66.48 & 75.34 \\
$2.00 \mathrm{~g} \mathrm{~mL}^{-1}$ & 58.71 & 71.41 & 78.86 \\
\hline
\end{tabular}

Keterangan: Angka yang diikuti huruf yang sama pada kolom yang sama, tidak berbeda nyata pada Duncan's Multiple Range Test (DMRT) pada taraf $\alpha=5 \%, \mathrm{MSA}=$ minggu setelah aplikasi

Tabel 3. Pengaruh ekstrak daun M. micrantha terhadap jumlah daun C. diffusa

\begin{tabular}{llll}
\hline \multirow{2}{*}{ Konsentrasi ekstrak } & \multicolumn{3}{c}{ Jumlah daun } \\
\cline { 2 - 4 } $0.00 \mathrm{~g} \mathrm{~mL}^{-1}$ (kontrol) & $1 \mathrm{MSA}$ & $2 \mathrm{MSA}$ & 27.46 \\
$0.33 \mathrm{~g} \mathrm{~mL}^{-1}$ & $29.39 \mathrm{a}$ & $33.13 \mathrm{a}$ & 20.86 \\
$0.67 \mathrm{~g} \mathrm{~mL}^{-1}$ & $15.25 \mathrm{c}$ & $21.77 \mathrm{dc}$ & 22.58 \\
$1.00 \mathrm{~g} \mathrm{~mL}^{-1}$ & $22.64 \mathrm{abc}$ & $24.65 \mathrm{abc}$ & 26.60 \\
$1.33 \mathrm{~g} \mathrm{~mL}^{-1}$ & $21.96 \mathrm{abc}$ & $26.35 \mathrm{abcd}$ & 20.79 \\
$1.67 \mathrm{~g} \mathrm{~mL}^{-1}$ & $16.52 \mathrm{bc}$ & $18.58 \mathrm{~d}$ & 31.28 \\
$2.00 \mathrm{~g} \mathrm{~mL}^{-1}$ & $23.82 \mathrm{ab}$ & $30.27 \mathrm{ab}$ & 23.61 \\
\hline
\end{tabular}

Keterangan: Angka yang diikuti huruf yang sama pada kolom yang sama, tidak berbeda nyata pada Duncan's Multiple Range Test (DMRT) pada taraf $\alpha=5 \%, \mathrm{MSA}=$ minggu setelah aplikasi

Tabel 4. Pengaruh ekstrak daun M. micrantha terhadap jumlah cabang C.diffusa

\begin{tabular}{lccc}
\hline \multirow{2}{*}{ Konsentrasi ekstrak } & \multicolumn{3}{c}{ Jumlah cabang } \\
\cline { 2 - 4 } $0.00 \mathrm{~g} \mathrm{~mL}^{-1}$ (kontrol) & $1 \mathrm{MSA}$ & $2 \mathrm{MSA}$ & $3 \mathrm{MSA}$ \\
$0.33 \mathrm{~g} \mathrm{~mL}^{-1}$ & 4.83 & 4.88 & 4.02 \\
$0.67 \mathrm{~g} \mathrm{~mL}^{-1}$ & 3.03 & 3.70 & 3.80 \\
$1.00 \mathrm{~g} \mathrm{~mL}^{-1}$ & 4.21 & 4.39 & 3.97 \\
$1.33 \mathrm{~g} \mathrm{~mL}^{-1}$ & 4.61 & 4.52 & 4.74 \\
$1.67 \mathrm{~g} \mathrm{~mL}^{-1}$ & 3.47 & 3.39 & 3.81 \\
$2.00 \mathrm{~g} \mathrm{~mL}^{-1}$ & 4.66 & 5.33 & 5.37 \\
\hline
\end{tabular}

Keterangan: Angka yang diikuti huruf yang sama pada kolom yang sama, tidak berbeda nyata pada Duncan's Multiple Range Test (DMRT) pada taraf $\alpha=5 \%, \mathrm{MSA}=$ minggu setelah aplikasi

memengaruhi tingkat toksisitas pada 2 dan 3 MSA. Aplikasi ekstrak daun $M$. micrantha dengan konsentrasi terendah yaitu $0.33 \mathrm{~g} \mathrm{~mL}^{-1}$ telah menunjukkan respon toksisitas.

Aplikasi ekstrak daun $M$. micrantha tidak hanya menekan pertumbuhan gulma $C$. diffusa, namun juga dapat menyebabkan kematian pada gulma $C$. diffusa (Tabel 6). Ekstrak daun M. micrantha meningkatkan persentase kematian gulma $C$. diffusa secara nyata pada 10 dan 15 HSA.
Pemberian ekstrak daun $M$. micrantha dengan konsentrasi terendah yaitu $0.33 \mathrm{~g} \mathrm{~mL}^{-1}$ telah menyebabkan kematian gulma $C$. diffusa pada 10 dan 15 HSA. Persentase kematian gulma $C$. diffusa mulai stagnan pada 25 dan 30 HSA.

Aplikasi ekstrak daun $M$. micrantha tidak mempengaruhi bobot kering gulma $C$. diffusa secara nyata (Tabel 7). Bobot kering $C$. diffusa pada kontrol yaitu 1.85 $\mathrm{g}$, sedangkan pemberian ekstrak daun $M$. micrantha dengan 
Tabel 5. Pengaruh ekstrak daun M. micrantha terhadap skor toksisitas C. diffusa

\begin{tabular}{lccc}
\hline \multirow{2}{*}{ Konsentrasi ekstrak } & \multicolumn{3}{c}{ Toksisitas } \\
\cline { 2 - 4 } $0.00 \mathrm{~g} \mathrm{~mL}^{-1}$ (kontrol) & $1 \mathrm{MSA}$ & $2 \mathrm{MSA}$ & $3 \mathrm{MSA}$ \\
$0.33 \mathrm{~g} \mathrm{~mL}^{-1}$ & $0.28 \mathrm{~b}$ & 0.51 & 1.17 \\
$0.67 \mathrm{~g} \mathrm{~mL}^{-1}$ & $1.26 \mathrm{a}$ & 1.31 & 1.83 \\
$1.00 \mathrm{~g} \mathrm{~mL}^{-1}$ & $1.09 \mathrm{a}$ & 1.40 & 1.87 \\
$1.33 \mathrm{~g} \mathrm{~mL}^{-1}$ & $1.36 \mathrm{a}$ & 1.38 & 1.92 \\
$1.67 \mathrm{~g} \mathrm{~mL}^{-1}$ & $1.68 \mathrm{a}$ & 1.67 & 1.66 \\
$2.00 \mathrm{~g} \mathrm{~mL}^{-1}$ & $1.29 \mathrm{a}$ & 1.00 & 1.34 \\
\hline
\end{tabular}

Keterangan: Angka yang diikuti huruf yang sama pada kolom yang sama, tidak berbeda nyata pada Duncan's Multiple Range Test (DMRT) pada taraf $\alpha=5 \%, \mathrm{MSA}=$ minggu setelah aplikasi

Tabel 6. Persentase kematian C. diffusa pada berbagai konsentrasi ekstrak daun M. micrantha

\begin{tabular}{lcccrrr}
\hline \multirow{2}{*}{ Konsentrasi ekstrak } & \multicolumn{5}{c}{ Persentase kematian gulma $(\%)$} \\
\cline { 2 - 7 } & $5 \mathrm{HSA}$ & $10 \mathrm{HSA}$ & $15 \mathrm{HSA}$ & 20 HSA & 25 HSA & 30 HSA \\
\hline $0.00 \mathrm{~g} \mathrm{~mL}^{-1}$ (kontrol) & 0 & $0.00 \mathrm{c}$ & $0.00 \mathrm{~b}$ & 0.00 & 0.00 & 0.00 \\
$0.33 \mathrm{~g} \mathrm{~mL}^{-1}$ & 2 & $10.00 \mathrm{ab}$ & $10.70 \mathrm{a}$ & 13.50 & 13.75 & 13.75 \\
$0.67 \mathrm{~g} \mathrm{~mL}^{-1}$ & 1 & $3.00 \mathrm{bc}$ & $1.08 \mathrm{~b}$ & 0.00 & 1.00 & 1.00 \\
$1.00 \mathrm{~g} \mathrm{~mL}^{-1}$ & 5 & $9.00 \mathrm{a}$ & $9.43 \mathrm{a}$ & 11.25 & 10.25 & 10.25 \\
$1.33 \mathrm{~g} \mathrm{~mL}^{-1}$ & 3 & $8.00 \mathrm{abc}$ & $7.50 \mathrm{ab}$ & 8.25 & 9.25 & 9.25 \\
$1.67 \mathrm{~g} \mathrm{~mL}^{-1}$ & 4 & $12.00 \mathrm{ab}$ & $10.75 \mathrm{ab}$ & 9.25 & 10.50 & 10.50 \\
$2.00 \mathrm{~g} \mathrm{~mL}^{-1}$ & 1 & $2.00 \mathrm{abc}$ & $2.00 \mathrm{ab}$ & 4.00 & 6.00 & 6.00 \\
\hline
\end{tabular}

Keterangan: Angka yang diikuti huruf yang sama pada kolom yang sama, tidak berbeda nyata pada duncan's multiple range test (DMRT) pada taraf $\alpha=5 \%, M S A=$ minggu setelah aplikasi

Tabel 7. Pengaruh ekstrak daun M. micrantha terhadap bobot kering C. diffusa

\begin{tabular}{lccc}
\hline \multirow{2}{*}{ Konsentrasi ekstrak } & \multicolumn{3}{c}{ Bobot kering $(\mathrm{g})$} \\
\cline { 2 - 4 } & $10 \mathrm{HSA}$ & $20 \mathrm{HSA}$ & $30 \mathrm{HSA}$ \\
\hline $0.00 \mathrm{~g} \mathrm{~mL}^{-1}$ (kontrol) & 1.85 & 2.50 & 2.93 \\
$0.33 \mathrm{~g} \mathrm{~mL}^{-1}$ & 1.69 & 1.42 & 1.91 \\
$0.67 \mathrm{~g} \mathrm{~mL}^{-1}$ & 1.41 & 2.17 & 2.13 \\
$1.00 \mathrm{~g} \mathrm{~mL}^{-1}$ & 1.59 & 1.92 & 2.21 \\
$1.33 \mathrm{~g} \mathrm{~mL}^{-1}$ & 1.60 & 1.33 & 1.77 \\
$1.67 \mathrm{~g} \mathrm{~mL}^{-1}$ & 1.63 & 1.62 & 2.69 \\
$2.00 \mathrm{~g} \mathrm{~mL}^{-1}$ & 2.01 & 2.20 & 1.93 \\
\hline
\end{tabular}

Keterangan: Angka yang diikuti huruf yang sama pada kolom yang sama, tidak berbeda nyata pada Duncan's Multiple Range Test (DMRT) pada taraf $\alpha=5 \%, M S A=$ minggu setelah aplikasi

konsentrasi terendah yaitu $0.33 \mathrm{~g} \mathrm{~mL}^{-1}$ menghasilkan bobot kering $C$. diffusa sebesar $1.69 \mathrm{~g}$ pada $10 \mathrm{HSA}$.

\section{Konsentrasi Optimal}

Penentuan konsentrasi optimal didapat dengan cara menurunkan persamaan regresi kurva respon peubah skor toksisitas gulma $C$. diffusa. Berdasarkan persamaan regresi $\mathrm{y}=-0.8646 \mathrm{x}^{2}+1.9811 \mathrm{x}+0.3826$, konsentrasi optimal ekstrak daun $M$. micrantha yang dapat menyebabkan toksisitas pada gulma $C$. diffusa sebesar $1.15 \mathrm{~g} \mathrm{~mL}^{-1}$. Hubungan konsentrasi ekstrak daun $M$. micrantha dengan persentase kematian gulma $C$. diffusa dapat dilihat pada Gambar 3. 


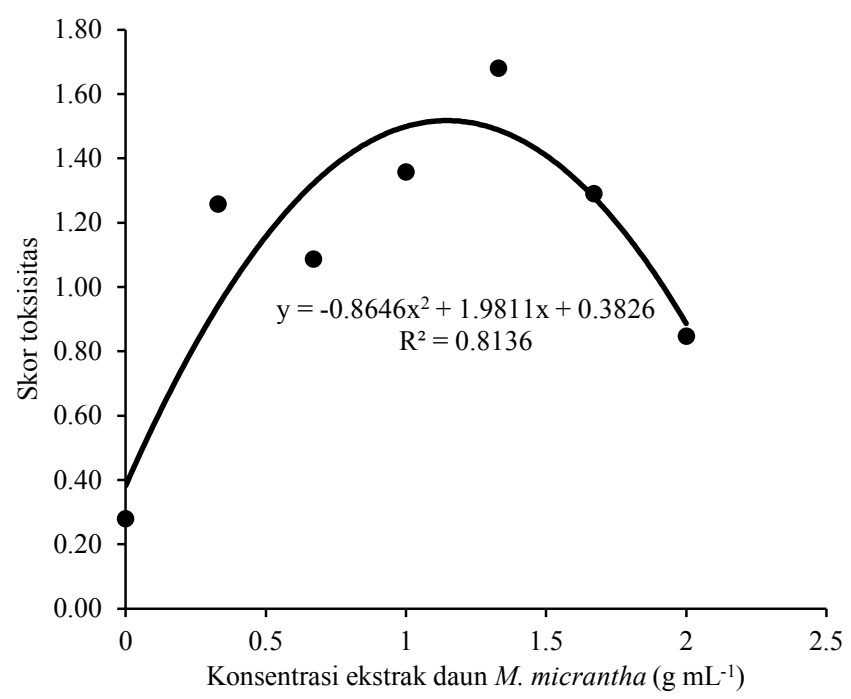

Gambar 3. Hubungan konsentrasi ekstrak daun M. micrantha dengan skor toksisitas gulma $C$. diffusa

\section{KESIMPULAN}

Gulma M. micrantha memiliki potensi sebagai bioherbisida yang ditandai oleh penghambatan pertumbuhan daun gulma $C$. diffusa sampai 2 MSA dan bersifat toksik bagi pertumbuhan gulma $C$. diffusa pada 1 MSA. Aplikasi ekstrak daun $M$. micrantha menyebabkan kematian gulma $C$. diffusa mulai 10 HSA sampai 15 HSA. Konsentrasi optimal ekstrak daun $M$. micrantha yang menyebabkan toksisitas pada gulma $C$. diffusa adalah $1.15 \mathrm{~g} \mathrm{~mL}^{-1}$.

\section{DAFTAR PUSTAKA}

Adin, E.R.P. Wardoyo, Mukarlina. 2017. Potensi ekstrak gulma cabang sembung rambat (Mikania micrantha H.B.K) sebagai bioherbisida pengendali gulma putri malu (Mimosa pudica L.). J. Protobiont 6:10-14.

Adriadi, A., Chairul, Solfiyeni. 2012. Analisis vegetasi gulma pada perkebunan kelapa sawit (Elais guineensis Jacq.) di Kolangan, Muaro Bulian, Batang Hari. J. Biol. Univ. Andalas 1:108-115.

Boyette, C.D., R.E. Hoagland, K.C. Stetina. 2015. Biological control of spreading dayflower (Commelina diffusa) with the fungal pathogen Phoma commelinicola. Agronomy 5:519-536.

Bravo-Monzon, A.E., A. Gonzalez-Rodriguez, F.J. Espinosa-Garcia. 2018. Spatial structure of genetic and chemical variation in native populations of the mile-a-minute weed Mikania micrantha. Biochem. Syst. and Ecol. 76:23-31.
Choudhury, M.R., P. Deb, H. Singha, B. Chakdar, M. Medhi. 2016. Predicting the probable distribution and threat of invasive Mimosa diplotricha Suavalle and Mikania micrantha Kunth in a protected tropical grassland. Ecol. Eng. 97:23-31.

Dilipkumar, M., T.S. Chuah, S.S. Goh, I. Sahid. 2017. Weed management issues, challenges, and opportunities in Malaysia. Crop Prot. 30:1-9.

Dong, L., X. Jia, Q. Luo, Q. Zhang, B. Luo, W. Liu, X. Zhang, Q. Xu, J. Tan. 2017. Phenolics from Mikania micrantha and their antioxidant activity. Molecules 22:1-10

Fariba, M., K. Javad, A.B. Mohammad. 2007. Allelopathic potential of Trifolium resupinatum L. and Trifolium alexandrum L. Weed Biol. Manag. 7:178-183.

Fuadi, R.T., K.P. Wicaksono. 2018. Aplikasi herbisida berbahan aktif atrazin dan mesotrion terhadap pengendalian gulma dan hasil tanaman jagung manis (Zea mays L. Saccharata) varietas bonanza. J. Prod. Tan. 6:767-774.

Hamidah, H.S., Mukarlina, R. Linda. 2015. Kemampuan ekstrak daun sembung rambat (Mikania micrantha H.B.K) sebagai bioherbisida gulma Melastoma affine D. Don. J. Protobiont 4:89-93.

Isaac, W.A.P., R.A.I. Brathwaite, J.E. Cohen, I. Bekele. 2007. Effects of alternative weed management strategies on Commelina diffusa Burm. infestations in fair trade banana (Musa spp.) in St. Vincent and the Grenadines. Crop Prot. 26:1219-1225.

Isaac, W., Z. Gao, M. Li. 2013. Managing commelina species: Prospects and limitations. p. 543-562. In A.J. Prices, J.A. Kelton (Eds.). Herbicides: Current Research and Case Studies in Use. InTech Publ. Kroasia. HR.

Kusuma, A.V.C., M.A. Chozin, D. Guntoro. 2017. Senyawa fenol dari tajuk dan umbi teki (Cyperus rotundus L.) pada berbagai umur pertumbuhan serta pengaruhnya terhadap perkecambahan gulma berdaun lebar. J. Agron. Indonesia 45:100-107.

Li, J., Jin Z. 2010. Potential allelopathic effects of Mikania micrantha on the seed germination and seedling growth of Coix lacryma-jobi. Weed Biol. Manag. 10:194-201.

Mortensen, D.A., J.F. Egan, B.D. Maxwell, M.R. Ryan, R.G. Smith. 2012. Navigating a critical juncture for sustainable weed management. BioSci. 62:75-84. 
Nicollier, G., A.C. Thompson. 1981. Essential oil and terpenoids of Mikania micrantha. Phytochem. 20:2587-2588.

Pebriani, R. Linda, Mukarlina. 2013. Potensi ekstrak daun sembung rambat (Mikania micrantha H.B.K.) sebagai bioherbisida terhadap gulma maman ungu (Cleome rutidosperma DC.) dan rumput bahia (Paspalum notatum Flugge). J. Protobiont 2:32-38.

Perez-Amador, M.C., V.M. Ocotero, R.I. Balzacar, F.G. Jimenez. 2010. Phytochemical and pharmacological studies on Micania micrantha H.B.K. (Asteraceae). Int. J. Exp. Bot. 79:77-80.

Puspita, Y. 2007. Studi Potensi Ekstrak Air Tajuk Sembung Rambat (Mikania micrantha H.B.K.) dan Daun Tembelekan (Lantana camara L.) untuk Mengendalikan Tiga Jenis Gulma. Skripsi. Fakultas Pertanian. Institut Pertanian Bogor. Bogor.
Riskitavani, D.V., K.I. Purwani. 2013. Studi potensi bioherbisida ekstrak daun ketapang (Terminalia catappa) terhadap gulma rumput teki (Cyperus rotundus). J. Sains Seni Pomits 2:2337-3520.

Sahid, I., N. Yusoff. 2014. Allelopathic effects of Chromolaena odorata (L.) King \& Robinson and Mikania micrantha H.B.K. on three selected weed species. AJCS 8:1024-1028.

Shen, S., M.D. Day, G. Xu, D. Li, G. Jin, X. Yin, Y. Yang, S. Liu, Q. Zhang, R. Gao, F. Zhang, R.L. Winston. 2018. The current status of biological control of weeds in southern China and future options. Acta Ecol. Sin. 38:157-164.

Xu, Q., H. Xie, H. Xiao, X. Wei 2013. Phenolic constituents from the roots of Mikania micrantha and their allelopathic effects. J. Agric. Food Chem. 61:73097314. 